Hift, H., Ouellet, L., Littlefield, J. W. \& Sanadi, D. R. (1953). J. biol. Chem. 204, 565.

Hunter, F. E. (1951). In Phosphorus Metabolism, 1, 297, ed. by W. D. McElroy and Bentley Glass. Baltimore: The Johns Hopkins Press.

Hunter, F. E. \& Hixon, W. S. (1949). J. biol. Chem. $181,67$.

Judah, J. D. (1951). Biochem. J. 49, 271.

Kaufman, S., Gilvarg, C., Cori, O. \& Ochoa, S. (1953). J. biol. Chem. 203, 869.

Kielley, W. W. \& Kielley, R. K. (1951). J. biol. Chem. 191, 485.

Krebs, H. A. \& Cohen, P. P. (1939). Biochem. J. 33, 1895.

Lardy, H. A. (1952). In The Biology of Phosphorus, p. 131, ed. by Lester F. Wolterink. Michigan State College Press. Lardy, H. A. \& Wellman, H. (1952). J. biol. Chem. 195, 215. Lardy, H. A. \& Wellman, H. (1953). J.biol. Chem. 201, 357. Lee, K. H. \& Eiler, J. J. (1953a). J. biol. Chem. 203, 705. Lee, K. H. \& Eiler, J. J. (1953b). J. biol. Chem. 203, 719.
Lewis, S. E. \& Slater, E. C. (1954). Biochem. J. 58, 207.

Loomis, W. F. \& Lipmann, F. (1949). J. biol. Chem. 179, 503.

Potter, V. R. \& Recknagel, R. O. (1951). In Phosphorus Metabolism, 1, 377, ed. by W. D. McElroy and Bentley Glass. Baltimore: The Johns Hopkins Press.

Sacktor, B. (1954). J. gen. Physiol. 37, 343.

Simon, E. W. (1953). Biol. Rev. 28, 453.

Slater, E. C. $(1953 a)$. Biochem. J. 53, 521.

Slater, E. C. $(1953 b)$. Nature, Lond., 172, 975.

Slater, E. C. \& Bonner, W. D. (1952). Biochem. J. 52, 185.

Slater, E. C. \& Cleland, K. W. (1953a). Biochem. J. 55, 566.

Slater, E. C. \& Cleland, K. W. (1953b). Biochem. J. 53, 577.

Slater, E. C. \& Holton, F. A. (1953). Biochem. J. 55, 530.

Slater, E. C. \& Lewis, S. E. (1953). Biochem. J. 55, xxvi.

Terner, C. (1953). Biochem. J. 55, xxix.

Watanabe, M. I. \& Williams, C. M. (1953). J.gen. Physiol. 37, 71.

\title{
Synthesis of Cellulose by Acetobacter xylinum
}

\section{PREPARATION OF FREEZE-DRIED CELLS CAPABLE OF POLYMERIZING GLUCOSE TO CELLULOSE*}

\author{
By S. HESTRIN AND M. SCHRAMM \\ Laboratory of Microbiological Chemistry, Department of Biochemistry, Hebrew University. \\ Hadassah Medical School, Jerusalem, Israel
}

(Received 20 April 1954)

Non-proliferating cells of Acetobacter xylinum acting on glucose in the presence of oxygen are known to synthesize cellulose (Hestrin, Aschner \& Mager, 1947; Hestrin, 1953). Hitherto, however, the factors determining rate and yield of the production of cellulose in this system have not been described quantitatively. In an earlier communication, a micromethod for the specific determination of cellulose in a biological mixture was presented (Schramm \& Hestrin, 1954a). The present paper describes the procedure for the separation of $A$. xylinum bacteria from their cellulose pellicle and the preparation of an essentially cellulose-free suspension of non-proliferating freeze-dried cells which polymerize glucose to high-polymer cellulose. Optimum conditions for the synthesis are described and the specific synthetic activity of the cells is evaluated. Some observations which relate to the mechanics of the growth of cellulose gel bodies are also presented.

The chemical mechanism of the synthesis of cellulose by $A$. xylinum will be the subject of a later communication.

* Experiments described in this communication were carried out by M.S. in the course of work leading to the Ph.D. degree.

\section{METHODS AND MATERIALS}

\section{Culture technique}

The following medium was used $(\%, w / v)$ : glucose, $2 \cdot 0$; peptone (Difco Bactopeptone), 0.5; yeast extract (Marmite), 0.5 ; disodium phosphate (anhydrous), 0.27 ; citric acid (monohydrate), $0.115 ; \mathrm{pH}$ adjusted to 6.0 with dil. $\mathrm{HCl}$ or $\mathrm{NaOH}$. The solution was cleared by filtration and sterilized by autoclaving. A shallow-layer quiescent-culture technique which favours rapid appearance of a surface pellicle and growth of the vigorously cellulose-synthesizing $A$. xylinum wild type (Schramm \& Hestrin, 1954b) was used. The medium was inoculated $1: 10$ with fluid from the liquid phase of a 3-day starter culture, distributed aseptically into large Petri dishes as a shallow fluid layer and incubated at $30^{\circ}$ at rest. The pellicles were harvested after $48 \mathrm{hr}$.

\section{Preparation of freeze-dried bacteria}

The separation of $A$. xylinum bacteria from their matrix of cellulose was based on the observation that cheesecloth retains the cellulose fibrils but allows the bacteria to pass (Hestrin et al. 1947). Sodium phosphate-citrate mixture (pH 6.0; final phosphate concn., $0 \cdot 01 \mathrm{~m}$ ) was used as buffer. At all stages of washing, the temperature of the milieu was kept below $6^{\circ}$ with ice. The use of this low temperature both conserved activity and protected the bacteria from agglutination in bodies of cellulose gel which might otherwise have formed during the early stages of the washing process from the traces of glucose in the cell milieu. 
The pellicles were cooled, drained and then pulped rapidly in a Waring Blendor (1 min. at high speed) under 5 vol. of buffer. The foam was skimmed off and the suspension of bacteria and fibrils was passed through 4 layers of cheesecloth. Residues on the cloth and the separated foam were stirred into fresh buffer and the procedure was repeated. The filtrates were centrifuged giving a pink paste. With the aid of some glass beads the paste was dispersed and washed in buffer twice by centrifuging. Finally the suspension was passed first through 6 layers of cheesecloth and then through glass wool. The filtrate was centrifuged and the bacteria were taken up in 5 vol. of buffer and freeze-dried using a low-temperature trap as moisture receiver. The dry light-brown product was stored at $-20^{\circ}$ in evacuated ampoules. It readily dispersed in water or in buffer solutions to yield a silky, fairly stable suspension.

The recovery of dried cells was of the order of $150 \mathrm{mg} . / 1$. of medium. This corresponded to about $62 \%$ of the dry wt. of the water-rinsed pellicle. There were approximately $10^{\circ}$ cells/mg. of the powder (cells enumerated in a bloodcount chamber). The nitrogen (Kjeldahl) content of the powder was $12 \%$ and the apparent cellulose content (method of Schramm \& Hestrin, 1954a) 0.5 $\pm 0.1 \%$.

Storage in the air-free ampoules at $-20^{\circ}$ for 2 months did not result in marked loss of the activity. When the powder was stored under air at room temperature, the activity declined markedly within two days.

\section{Measurement of synthetic activity}

The standard reaction mixture was made up to a total volume of $20 \mathrm{ml}$. in a $125 \mathrm{ml}$. stoppered Erlenmeyer flask to contain : freeze-dried cells, $10 \mathrm{mg}$.; glucose, $0.2 \mathrm{M}$; sodium citrate, $0.02 \mathrm{M}, \mathrm{pH} 6.4$; gas phase, $\mathrm{O}_{2}$. The reaction flask was shaken reciprocally at a rate of $100 \mathrm{cyc} . / \mathrm{min} .\left(90^{\circ} \mathrm{arc}\right)$ in a water bath at $30 \pm 0 \cdot 1^{\circ}$. The reaction was terminated (after 1-3 hr.) by adding enough ether to cover the surface.

\section{Analytical methods}

Cellulose was determined as previously described (Schramm \& Hestrin, 1954a). The cellulose content at zero time was deducted from the total yield to obtain the amount formed.

Oxygen uptake was measured manometrically in a Warburg flask with an alkali wick in the centre well.

The radioactivity of ${ }^{14} \mathrm{C}$ was measured with a thin-window Geiger-Müller tube. The glucose solution for the measurement was taken up in a disk of filter paper and dried in the planchet. The cellulose sample for measurement was purified as described by Schramm \& Hestrin (1954a) and spread out in a film on the bottom of the planchet so that it had roughly the same dimensions and form as the filterpaper disk. The counts were corrected for self-absorption. After the measurement of radioactivity, the amount of the cellulose in the sample was determined chemically. When a non-radioactive sample of cellulose was purified after prior immersion in $\left[{ }^{14} \mathrm{C}\right]$ glucose solution, the radioactivity of the purified specimen was negligible.

\section{Mechanical agitation}

Reciprocal motion was produced on a wrist shaker $\left(90^{\circ}\right.$ arc; 100 cyc./min.) and swirling motion on a Ross-Kershaw apparatus (A. H. Thomas and Co., Philadelphia, U.S.A.).

\section{Measurement of infrared absorption}

A foil of the synthesized cellulose was used. This was prepared by incubating the standard reaction mixture for $20 \mathrm{hr}$. without agitation. The foil was rinsed in water, purified by storage in $1 \% \mathrm{NaOH}$, and rinsed again in water. The infrared absorption spectrum was kindly worked out by Drs J. Rowen and R. Nusbaum, Physiological Chemistry Department, Medical School, University of California, U.S.A., according to the procedure of Forziati \& Rowen (1951) with the aid of a fine-grating instrument of high resolving power. The reference for comparison was a somewhat thicker foil which had been obtained from the surface of a $48 \mathrm{hr}$. culture of $A$. xylinum (cf. also, Shirk \& Greathouse, 1952).

\section{RESULTS}

\section{Synthesis of cellulose from $\left[{ }^{14} \mathrm{C}\right]$ glucose}

Synthesis of the cellulose from added glucose was demonstrated unambiguously by using $\left[{ }^{14} \mathrm{C}\right]$ glucose as a substrate. The radioactivity of the cellulose was between 78 and $88 \%$ of the value required on the assumption that the carbon of the cellulose is derived solely from the added glucose. An experiment in triplicate is presented in Table 1 . While the possibility cannot be excluded that carbon from an unknown endogenous source participated in cellulose synthesis, it is clear that the major carbon source was the exogenous glucose. Synthesis of radioactive cellulose from $\left[{ }^{14} \mathrm{C}\right]$ glucose has been described previously in the cotton boll (Greathouse, 1953) and in growing cultures of $A$. xylinum (Minor, Greathouse, Shirk, Schwartz \& Harris, 1954) and $A$. acetigenum (Bourne \& Weigl, 1954).

\section{Kinetic properties of the polymerizing system}

Glucose and oxygen supplied together were necessary for synthesis of cellulose by the freezedried cells. When the latter had been prepared with rigid adherence to the procedure described, the apparent cellulose content of the standard reaction mixture at zero time was a small fraction ( $<10 \%$ ) of the total found at the end of $2 \mathrm{hr}$. When the cells were shaken, either under oxygen in the absence of glucose or under nitrogen (pure, or admixed with

\section{Table 1. Synthesis of cellulose from $\left[{ }^{14} \mathrm{C}\right]$ glucose}

$\left[{ }^{14} \mathrm{C}\right]$ Labelled glucose $(36.8 \mu$ moles; total counts, $5600 /$ min.) and dried cells (10 mg.) in total vol. $3.6 \mathrm{ml}$. Conditions otherwise standard. Reaction time, $2 \mathrm{hr}$.

$\begin{array}{cccc}\text { Expt. } & \begin{array}{c}\text { Cellulose } \\ \text { formed }\end{array} & \overbrace{\begin{array}{c}\text { Total } \\ \text { no. }\end{array}}^{\text {Radioactivity of cellulose }} & \begin{array}{c}\text { \% of initial } \\ \text { activity* }\end{array} \\ 1 & 3.72 & 498 & 88 \\ 2 & 3.63 & 483 & 87 \\ 3 & 3.49 & 456 & 86\end{array}$

* Specific activity of polymerized glucose as $\%$ of that of added glucose (counts $/ \mathrm{min} . / \mu$ mole). 
carbon dioxide) in the presence of glucose, the low initial apparent cellulose content of the cells remained constant. In the absence of glucose the $\mathrm{O}_{2}$ uptake rate, too, was negligible, being less than $0.01 \mu \mathrm{mole} / \mathrm{mg} . / \mathrm{hr}$. In the presence of glucose the $\mathrm{O}_{2}$ uptake rate was about $4 \mu$ moles $/ \mathrm{mg}$. $/ \mathrm{hr}$.

The course of the synthetic reaction under the standard test conditions is illustrated by Fig. 1. The rate was maximal from the outset. There was a relatively rapid early decline. Thereafter, the rate either remained practically constant or declined slowly over a period of several hours. The $\mathrm{pH}$ was held during this time within $0 \cdot 1 \mathrm{pH}$ unit of the initial value, as the capacity of the citrate buffer was sufficient to neutralize the acids (chiefly gluconic) formed oxidatively by the cells from glucose. Variation of glucose concentration within a wide range (3-200 mM) was without effect on the initial rate of the synthesis. Variation of shaking rate (80-120 cyc./min.) did not alter the synthesis course and rate.

The plot of the amount of cellulose formed against the amount of cells was a straight line which passed through the origin (Fig. 1). Replicate assays agreed within $\pm 3.5 \%$. In the tested range of cell concentration ( $₹ 1 \mathrm{mg} . / \mathrm{ml}$.) and incubation time (1-3 hr.), specific synthetic activity ( $\mu$ moles glucose polymerized/mg. cells (dry wt.)/hr.) could thus be

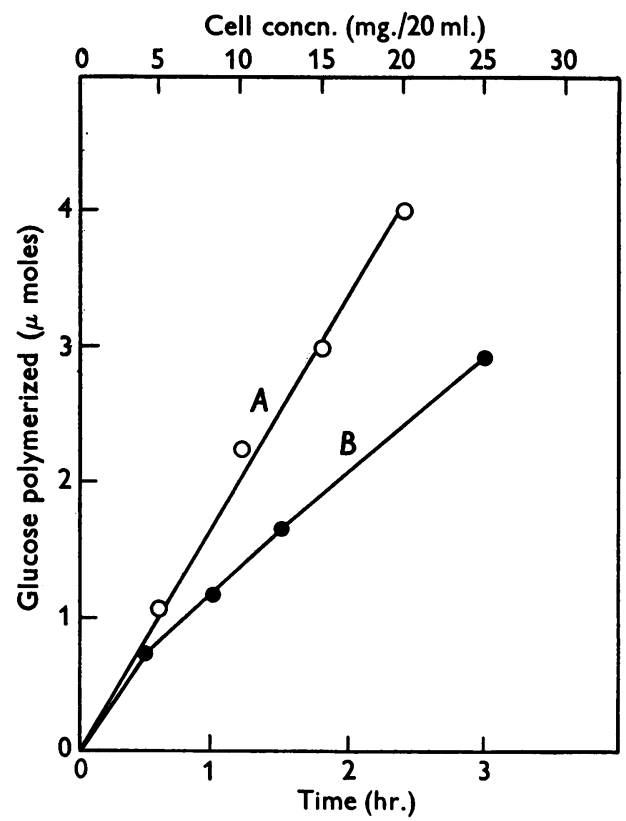

Fig. 1. Influence of reaction time and cell concentration on cellulose production. Curve $A$ shows the glucose polymerized as a function of cell concn.; curve $B$ shows the glucose polymerized as a function of time. The reaction time was $1.5 \mathrm{hr}$. for curve $A$. The cell concn. was $0.5 \mathrm{mg}$./ ml. for curve $B$. Conditions otherwise were standard. Experiments involved two different batches of cells. calculated by linear extrapolation. The cellulosesynthesizing power of the freeze-dried cells was $50-100 \%$ of that of the freshly harvested cells. Under standard conditions the specific synthetic activity of the freeze-dried preparation fell in the range of $0 \cdot 1-0.25 \mu \mathrm{mole} / \mathrm{mg}$. $/ \mathrm{hr}$, the value depending on the batch.

The complete course of the synthesis was recorded for the case of limiting glucose concentration (Fig. 2). In such a reaction mixture, when the rate of synthesis in this reaction mixture had become negligible at the end of an incubation time of $4 \mathrm{hr}$., chromatographic analysis showed no glucose. Since the cellulose formed was not decreased when incubation was continued after no glucose remained, the overall process of the synthesis can be regarded as essentially irreversible. The terminal yield of the cellulose was $26 \%$ of the glucose initially added. This yield is several-fold higher than any recorded hitherto for cellulose synthesis either by $A$. xylinum or any related species (cf. Tarr \& Hibbert, 1931; Kaushal \& Walker, 1951).

The effect of $\mathrm{O}_{2}$ tension is illustrated in Fig. 3. The synthesis velocity with glucose in excess was about half-maximal at $\mathrm{O}_{2}$ tension $20 \%$ and gradually approached maximum at tension $100 \%$. The sensitive dependence of the synthesis velocity on $\mathrm{O}_{2}$ tension explains in part why the production of cellulose in an undisturbed culture of $A$. xylinum is restricted to the liquid-air interphase (Schramm \& Hestrin, 1954b).

The effect of $\mathrm{pH}$ on the rates of the polymerization and oxidation are compared in Table 2. Both the polymerization and $\mathrm{O}_{2}$ uptake were maximal in the $\mathrm{pH}$ range 5-7. The rate of the polymerization is retarded relatively to $\mathrm{O}_{2}$ uptake in the $\mathrm{pH}$ region below 5 .

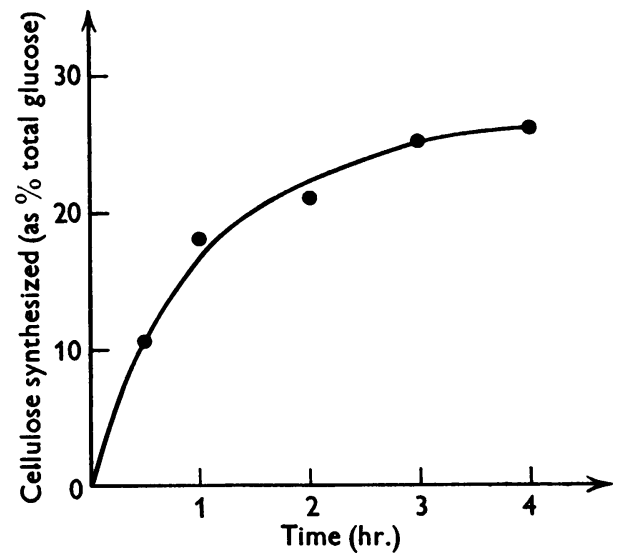

Fig. 2. Production of cellulose in reaction mixture containing limiting concentration of glucose. The digest contained $10 \mathrm{mg}$. dried cells and $10 \mu$ moles glucose in total vol. $2 \cdot 0 \mathrm{ml}$. Conditions otherwise standard. 


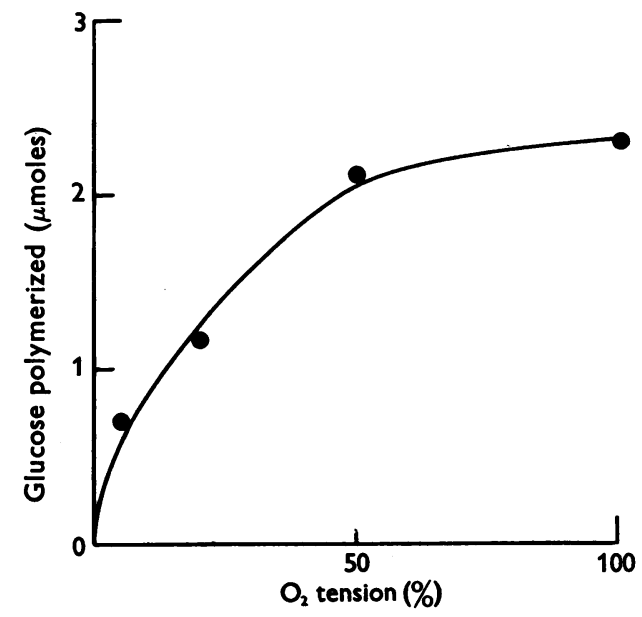

Fig. 3. Influence of $\mathrm{O}_{2}$ tension on synthesis velocity. $\mathrm{O}_{2}$ tension was varied by diluting gas phase with nitrogen. The digest contained $15 \mathrm{mg}$. dried cells and McIlvaine's phosphate-citrate buffer (pH 6.0; diluted 12-fold). Conditions otherwise standard.

Table 2. Rates of cellulose synthesis and oxygen uptake of freeze-dried cells of Acetobacter xylinum as a function of $\mathrm{pH}$

Conditions were standard except for use of sodium phosphate-citrate mixture as buffer (final concn. as to phosphate, $0.01 \mathrm{~m})$. The $\mathrm{O}_{2}$ uptake was determined for the period $0.5-1.0 \mathrm{hr}$.

\begin{tabular}{|c|c|c|c|c|}
\hline & & $(\mu \mathrm{m}$ & $\begin{array}{l}\text { ctivity } \\
\text { es/mg./hr. }\end{array}$ & \\
\hline \multicolumn{2}{|c|}{$\mathrm{pH}$} & Glucose & $\mathrm{O}_{2}$ & \\
\hline Initial & Final & $(a)$ & (b) & $b / a$ \\
\hline $\begin{array}{l}2 \cdot 9 \\
4 \cdot 0 \\
5 \cdot 2 \\
6 \cdot 4 \\
7 \cdot 3 \\
8 \cdot 5\end{array}$ & $\begin{array}{l}2 \cdot 9 \\
3 \cdot 9 \\
4 \cdot 7 \\
6 \cdot 0 \\
6 \cdot 9 \\
7 \cdot 3\end{array}$ & $\begin{array}{l}0.04 \\
0.12 \\
0.21 \\
0.20 \\
0.22 \\
0.12\end{array}$ & $\begin{array}{l}3 \cdot 2 \\
4 \cdot 5 \\
4 \cdot 2 \\
4 \cdot 8 \\
4 \cdot 2 \\
\mathbf{3} \cdot 2\end{array}$ & $\begin{array}{l}80 \\
38 \\
20 \\
24 \\
19 \\
27\end{array}$ \\
\hline
\end{tabular}

Table 3. Qualitative properties of cellulose formed from glucose by freeze-dried cells of Acetobacter xylinum

\section{Colour reactions}

(a) Test for cellulose with iodine-zinc chloride reagent: positive (blue-violet stain).

(b) Reduction of copper reagents: negative prior to hydrolysis; positive after hydrolysis.

(c) Test for glucose with phosphoric acid-pyrocatechol reagent (Hestrin \& Mager, 1947): positive.

(d) Test for non-glucose sugars with phosphoric acid (Hestrin \& Mager, 1947): negative.

\section{Solubility tests}

(a) Liquids with dispersing action: acetic anhydride (in presence of catalyst); conc. mineral acids $\left(\mathrm{H}_{2} \mathrm{SO}_{4}\right.$; $\mathrm{HCl} ; \mathrm{H}_{3} \mathrm{PO}_{4}$ ); Schweizer's reagent (slow action).

(b) Liquids without dispersing action: common organic solvents (ethanol, ether, acetone); weak acids and dil. strong mineral acids $\left(5 \mathrm{~N}-\mathrm{H}_{2} \mathrm{SO}_{4}\right.$, glacial acetic acid); aqueous alkali ( $\mathrm{N}$ and $5 \mathrm{~N}-\mathrm{NaOH}$ ).

\section{Identification of polymerization product}

The general appearance and behaviour of the polymerization product closely recall the gel produced from glucose by $A$. xylinum in culture. The product has been identified unambiguously on the basis of the infrared absorption spectrum which was kindly prepared by Drs Rowen and Nusbaum (Fig. 4). The material on this basis can be regarded as high-polymer, native, crystalline (type 1) cellulose. As has been pointed out by Dr Rowen in a personal communication, the identity of the absorption peaks found with synthetic and natural cellulose of $A$. xylinum in the spectral region 2750 $3750 \mathrm{~cm} .^{-1}$ suggests that even the fine-structure hydrogen bonding of these specimens is identical. A detailed report will be presented by Drs Rowen and Nusbaum elsewhere.

Supplementary observations confirming the identification of the product are assembled in Table 3. An X-ray diffraction diagram of the

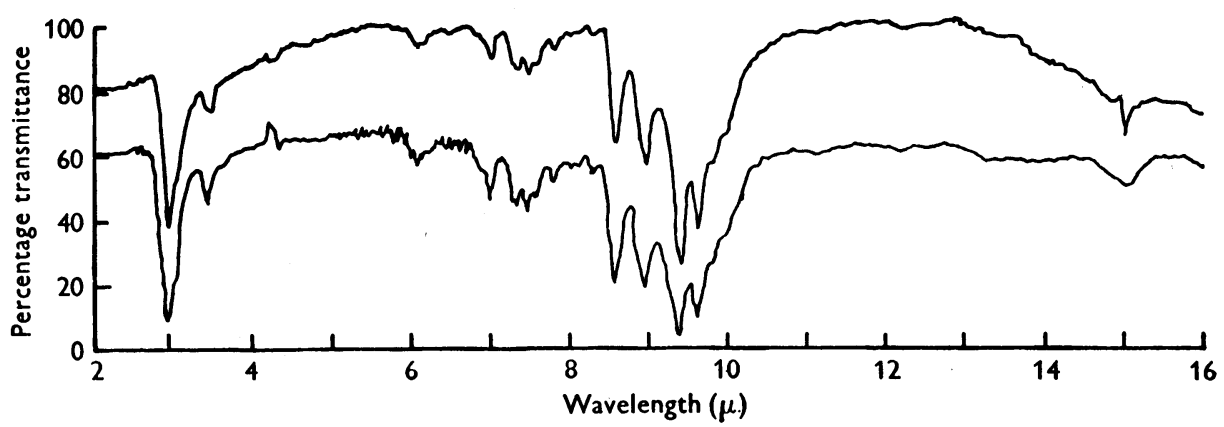

Fig. 4. Infrared absorption spectrum of cellulose foil produced from glucose by freeze-dried Acetobacter xylinum. For details of procedure see under Methods and Materials. The upper curve is for cellulose foil synthesized by freezedried cells; the lower curve is for cellulose foil from culture of $A$. xylinum. 
synthetic cellulose was obtained by Drs Alexander and Fraenkel, Department of Physics, Hebrew University, Jerusalem, Israel, and found to be identical in all important respects with a diagram afforded under the same conditions by cotton.

Polysaccharide products other than cellulose (the alkali-insoluble fraction) have not been detected. A water-soluble extract of a reaction mixture after $2 \mathrm{hr}$. incubation was devoid of any material precipitable by ethanol $(80 \%, v / v)$. On hydrolysis in $2 \mathrm{~N}$ sulphuric acid for $1 \mathrm{hr}$. in a boiling-water bath, the fraction insoluble in water and soluble in hot $4 \%$ sodium hydroxide gave approximately the same yield of reducing sugar as a corresponding fraction prepared from cells that had been incubated without glucose. The water-insoluble alkali-soluble polysaccharide content of $A$. xylinum, as measured by the anthrone method of Fales (1951), was $17 \mu \mathrm{g} . /$ mg. On the incubation of $A$. xylinum with glucose during $2 \mathrm{hr}$. under the conditions of the standard reaction mixture, this value was not changed significantly.

\section{Gross morphology of gel}

Gross alterations in the appearance of the reaction mixture began immediately after the addition of glucose. These did not occur in the absence of either glucose or oxygen. The alterations followed a characteristic sequence (Fig. 5) : silky suspension $\rightarrow$ loose fluff $\rightarrow$ floccules $\rightarrow$ large bodies. The bulk of the cells present initially free in suspension was

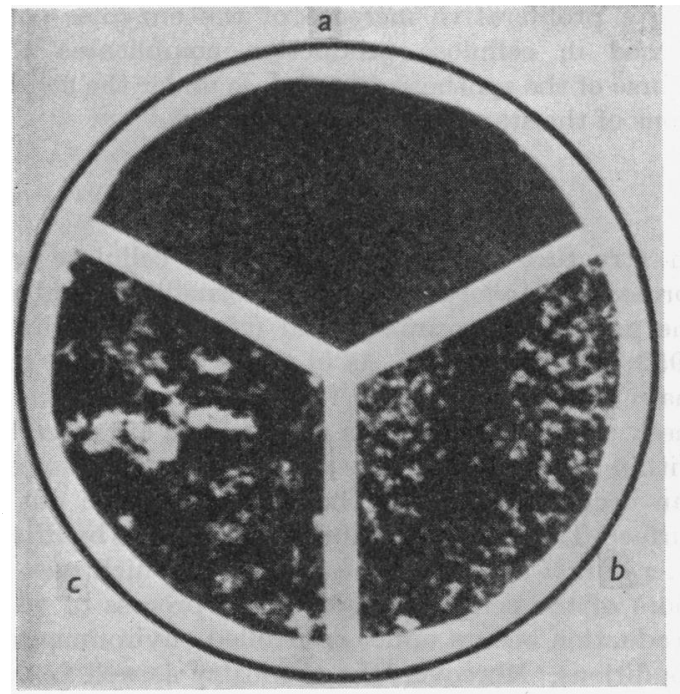

Fig. 5. Appearance of cell suspension at successive times of reaction. Conditions standard. Mixture was photographed in a Petri dish over a dark background. Sectors $a, b, c$ are from photographs taken 0,5 and $30 \mathrm{~min}$. respectively following initiation of reaction by glucose. $\times 1$. incorporated in the formed gel. The final form assumed by the latter was a function of the intensity and type of agitation applied during reaction. The product of an undisturbed reaction mixture was a single, thin floating foil. That of a mixture agitated by reciprocal shaking was a single body of irregular form (Fig. 6). Several spherical and stellate bodies were afforded terminally by a swirled reaction mixture (Fig. 7).

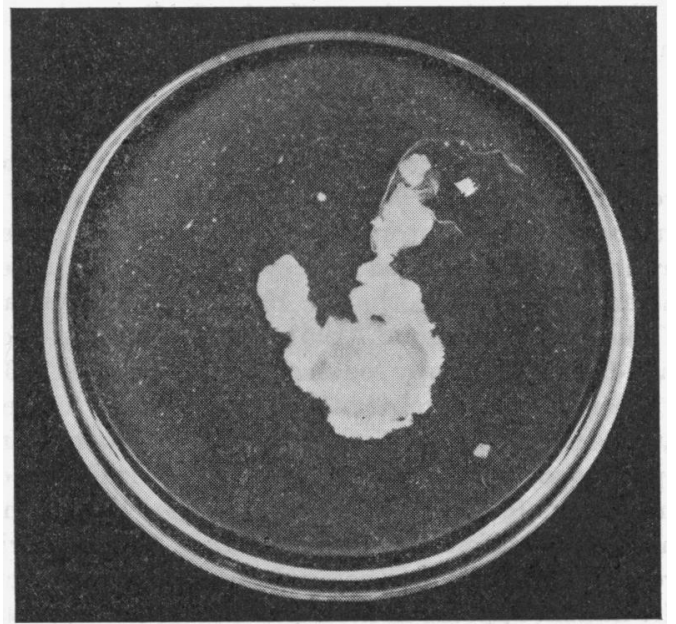

Fig. 6. Single gel body formed in reciprocally shaken reaction mixture. Conditions standard. Suspension was photographed in a Petri dish against a dark background at reaction time $3 \mathrm{hr}$. Note piece of fragile membrane attached to the gel body on the right-hand top. This was formed after the shaking had been terminated.

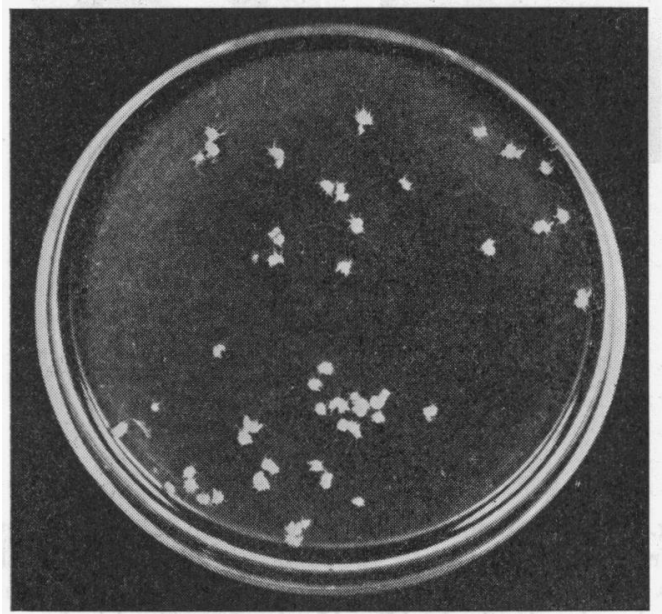

Fig. 7. Stellate gel bodies formed in swirled reaction mixture. Conditions standard except that mixture was agitated by swirling. Suspension was photographed in a Petri dish against a dark background at reaction time $4 \mathrm{hr}$. Note the fine radial arms. $\times 0 \cdot 8$. 
The synthesis continued without conspicuous fall of rate for long after the gel had become macroscopically visible and after it had tightly incorporated the bulk of the initially free bacteria. Thus the bacteria continue to synthesize cellulose even after their incorporation in the gel. Hence the gel framework must be penetrated readily by glucose and oxygen. As additional chains are intercalated, the gel may be expected to acquire increased tensile strength. This is observed.

The relative shares in synthesis of cells inside and outside the gel will be discussed elsewhere.

\section{Microscopic morphology of gel}

The microstructure of a cellulose gel produced by growing cells of $A$. xylinum has been described by a number of investigators (for electron microscopy see Franz \& Schiebold, 1943; Frey-Wyssling \& Mühlethaler, 1946; Mühlethaler, 1948, 1949; Kaushal, Walker \& Drummond, 1951; Renby, 1952 $a$; for dark-field microscopy see Aschner \& Hestrin, 1946).

Electron micrograms of specimens of gel formed by freeze-dried $A$. xylinum acting on glucose are reproduced in Fig. 8, with the kind permission of Drs Hirschfeld and Volcani of the Weizmann Institute of Science, Rehovot, Israel. The bacteria are seen enveloped by their polymerization product. The matrix appears in most parts to be amorphous. Fibrous strands are sometimes discernible within the sheet. Often fibres are seen crossing a torn area.

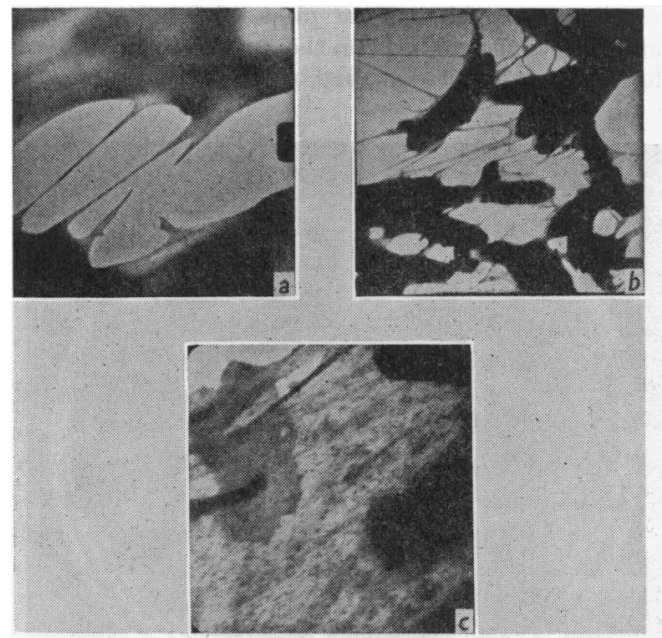

Fig. 8. Electron micrographs of gel formed from glucose by freeze-dried Acetobacter xylinum. Mixture agitated with a stream of oxygen at $20^{\circ}$. Glucose, $0.003 \mathrm{M}$. Conditions otherwise standard. After 15 min. a small gel body was picked up on to a stainless-steel grid (200 mesh), dried, rinsed in water, and examined under an RCA electron microscope, model EMU-2 A; $a$ and $b$ magnification about $\times 3600$; $c$ magnification about $\times 15600$. Dark shadows represent dried bacteria.
The predominantly amorphous structure of dried material is consistent with the suggestion that the framework of the native gel is a loose three-dimensional reticulum whose strands individually are mostly below the limit of resolution of the microscope. We have no evidence from the present study that the initially formed bacterial cellulose product consists largely of units 50-300 such as are present abundantly in well-crystallized cellulose specimens (Ranby, 1952b; Preston, 1952).

\section{Influence of freeze-drying on viability of cells}

Graded amounts of freshly harvested and freezedried cells were inoculated into $5 \mathrm{ml}$. of sterile nutrient medium. Presence of viable cells was revealed by the production of a surface pellicle within 2 weeks at $30^{\circ}$ in undisturbed medium. Whereas the minimum amount of the freshly harvested bacteria giving a positive growth test was $10^{-9} \mathrm{mg}$., that of the freeze-dried bacteria was $10^{-7} \mathrm{mg}$. This suggests that the drying had resulted in the loss of viability of $>90 \%$ of the cells. Loss of specific synthetic activity on drying was $<25 \%$ in the same experiment. Nitrogenous nutrients (peptone, yeast extract) did not affect either the specific synthetic activity or the course of the reaction in the standard conditions during $3 \mathrm{hr}$. Whereas synthesis occurs at $37^{\circ}$ as well as at $30^{\circ}$, cell growth in nutrient medium was rapid at $30^{\circ}$ but was suppressed at $37^{\circ}$.

These findings suggest that neither an adaptive nor a proliferative increase of the enzymes concerned in cellulose production complicates the course of the synthesis of cellulose under the conditions of the standard reaction mixture.

\section{DISCUSSION}

In structure and composition the cellulose gel formed by Acetobacter xylinum formally resembles the green-plent primary wall (cf. Frey-Wyssling, 1952; Preston, 1952). As in the primary wall, the main mass is water, the framework is a spacious mesh of cellulose; centres of synthesis are discrete within the network, and the addition of cellulose can occur both within the gel and on the outer surface. The process of cellulose production by dried A. xylinum thus affords a system in which one or more of the terminal steps of the process of wall production occurs under controlled environmental conditions. Moreover, the chemistry as well as the mechanics of cellulose production by a green plant and by $A$. xylinum have points of similarity. Thus it has been shown that isolated tissues of a green plant require exogenous carbohydrate (glucose) and oxygen for net production of cellulose (Brown, Reith \& Robinson, 1952). 
For convenience as a research tool, A. xylinum presents distinctive merits of which the more important are the following :

(1) The rate of production of cellulose by the bacteria is of the same order of magnitude as the rates of production of reserve polysaccharides by slices of animal tissues, the activities being calculated to the basis of tissue dry weight.

(2) The synthetic activity withstands freezedrying and subsequent prolonged storage.

(3) The cells are cellulose-free and readily dispersible.

(4) The endogenous rates of polymerization of glucose and uptake of oxygen are negligibly low.

(5) The cellulose formed by the bacteria is a wellknown standard type, the crystalline high-polymer group which has been represented classically by the $\alpha$-cellulose of cotton.

(6) The celulose is unencumbered by lignin, hemicellulose, pectin or other incrusting substances.

(7) The synthesis occurs from a defined substrate in a system which is practically free from net synthesis of any other polysaccharide.

(8) The reaction occurs under controlled conditions in a mixture of definite composition and follows a simple kinetic course uncomplicated by cell proliferation or adaptive enzyme synthesis.

(9) The polymer product is accumulated exclusively in the extracellular phase and there can readily be visualized.

At the electrolyte concentration of cellular fluids, hydrophobic micelles of high-polymer cellulose precipitate (Ranby, 1952b) and thus might be expected to accumulate near the locus of production. However, the cells of $A$. xylinum, as extracted mechanically from their pellicle, are practically cellulose-free (apparent cellulose $\sim 0.5 \%$ of the total dry weight). Since cellulose chains are not accumulated within the cells, the possibility that the chains are formed extracellularly must be considered.

The apparent non-accumulation of cellulose in the cell interior suggests strongly that cellulose itself is not formed within the cells. The same finding tends also to discourage the notion that a spontaneously polymerizable precursor of cellulose, if indeed such a precursor exists in this system, is one formed inside the cells, as it would be necessary in that case to make the additional assumption that the cells possess a specific mechanism for prevention of spontaneous polymerization of the precursor in the intracellular phase. There has been a suggestion that the production of cellulose in $A$. xylinum depends on an extracellular enzyme (Mühlethaler, 1949). It has been shown above, however, that the cells form cellulose immediately on contact with glucose and oxygen even after thorough washing. If an extracellular enzyme had been necessary for the synthesis, the washed cells would have been either inactive or active only after a lag period.

Thus it seems probable that the terminal catalyst of the enzyme complement concerned in cellulose production is situated on the outer bacterial surface. On this view the cell membrane of $A$. xylinum could be regarded as resembling an inverted cytoplasmic membrane of a green-plant cell. The product of the surface reaction would have to be either a finished cellulose chain or a spontaneously polymerizable precursor of such a chain. In either case the ultimate orientation of the polymer chains as fibrils would be a non-enzymic process occurring in the extracellular phase.

On the estimate that there are $10^{\circ}$ bacteria $/ \mathrm{mg}$. in the preparation of $A$. xylinum, the observed highest level of the specific synthetic activity of the bacteria (0.25 $\mu$ mole glucose polymerized/mg./hr.) corresponds to an hourly polymerization rate of the order of $1.5 \times 10^{8}$ glucose residues per cell. The surface area of a bacterium is about $1 \mu^{2} \mathrm{~A}$ cellulose chain $1 \mu$. long consists of about $2 \times 10^{3}$ glucose residues. On this basis there should be room on the surface of a bacterium for about $4 \times 10^{6}$ glucose residues. This would lead to the estimate that the rate of produc. tion of cellulose on the bacterial surface under standard reaction conditions is of the order of $10^{2}$ monomer monolayers/hr.

\section{SUMMARY}

1. A procedure for the preparation of Acetobacter xylinum in the form of a cellulose-free suspension of washed freeze-dried cells is described in detail.

2. Non-viable freeze-dried cells in optimum reaction conditions polymerized glucose to cellulose at a rate of $0.25 \mu \mathrm{mole} / \mathrm{mg}$. $/ \mathrm{hr}$., corresponding to a production of cellulose on the bacterial surface at a rate in the order of $10^{2}$ monomer monolayers $/ \mathrm{hr}$.

3. Synthesis was attended by a rapid decline in the turbidity of the cell suspension and formation of a macroscopic cellulose gel body. The gross shape of the latter was a function of the type and intensity of the agitation during synthesis.

4. The polymerization product has been characterized on the basis of solubility, qualitative chemical properties, infrared absorption, X-ray diffraction, and electron micrography, and identified as high-polymer, native, crystalline (type 1) cellulose.

5. At least $78 \%$ of the carbon of the polymer product was derived from exogenously added glucose. Synthesis was negligible in absence of glucose or oxygen. Synthesis was immediate in onset, progressive in course, variable linearly in rate with cell concentration and essentially irreversible. The optimum $\mathrm{pH}$ was in the range 5-7. The rate was about half-maximum at oxygen tension 
$20 \%$ and approached maximum at tension $100 \%$. At low initial glucose concentration, the terminal yield of cellulose was $26 \%$ of the total glucose.

6. Whereas the enzyme system for synthesis largely withstood freeze-drying, the latter incapacitated $>90 \%$ of the cells for proliferation.

7. Kinetics of synthesis, properties of the cellulose, and the negligible cellulose content of the cells suggest that a constituent of the outer surface of the bacteria is a terminal catalyst of the production of cellulose.

8. Similarities between cells of $A$. xylinum and green plants and the use of $A$. xylinum as a model for the study of cell-wall production are evaluated.

We are indebted to Professor M. Aschner for advice and to many colleagues for generous help. Sincerest thanks are tendered to Dr J. Mager and Mrs B. Wolman for valuable collaboration in an early stage of this investigation, to Dr J. Rowen and Dr R. Nusbaum for the infrared absorption spectra and their interpretation, to Dr B. Volcani and Dr F. Hirschfeld for the electron microgram productions and to Dr E. Alexander and Dr B. Fraenkel for the X-ray diffraction diagrams.

\section{REFERENCES}

Aschner, M. \& Hestrin, S. (1946). Nature, Lond., 157, 659. Bourne, E. J. \& Weigl, A. (1954). Chem. \& Ind. no. 5, 132. Brown, R., Reith, W. S. \& Robinson, E. (1952). Symp. Soc. exp. Biol. 6, 329.
Fales, F. W. (1951). J. biol. Chem. 193, 110.

Franz, E. \& Schiebold, E. (1943). J. makromol. Chem. $1,3$. Frey-Wyssling, A. (1952). Symp. Soc. exp. Biol. 6, 320.

Frey-Wyssling, A. \& Mühlethaler, K. (1946). J. Polym. Sci. 3, 172 .

Forziati, F. H. \& Rowen, J. W. (1951). J. Res. nat. Bur. Stand. 46, 38.

Greathouse, G. A. (1953). Science, 117, 553.

Hestrin, S. (1953). Symp. on Microbiol. Metabolism, Instituto Superiore di Sanità, Rome, pp. 63-70.

Hestrin, S., Aschner, M. \& Mager, J. (1947). Nature, Lond., $159,64$.

Hestrin, S. \& Mager, J. (1947). Analyt. Chem. 19, 1032.

Kaushal, R. \& Walker, T. K. (1951). Biochem. J. 48, 618.

Kaushal, R., Walker, T. K. \& Drummond, D. G. (1951). Biochem. J. 50, 128.

Minor, F. W., Greathouse, G. A., Shirk, H. G., Schwartz, A. M. \& Harris, M. (1954). J. Amer. chem. Soc. 76, 1658.

Mühlethaler, K. (1948). Makromol. Chem. 2, 143.

Mühlethaler, K. (1949). Biochim. biophys. Acta, 3, 527.

Preston, R. D. (1952). Symp. Soc. exp. Biol. 6, 348.

Ranby, B. G. (1952a). Ark. Kemi, 4, 249.

Ranby, B. G. (1952b). T.A.P.P.I. 35, 53.

Schramm, M. \& Hestrin, S. (1954a). Biochem. J. 56, 163.

Schramm, M. \& Hestrin, S. (1954b). J. gen. Microbiol. 11, 123.

Shirk, H. G. \& Greathouse, G. A. (1952). Analyt. Chem. 24, 1774.

Tarr, H. L. A. \& Hibbert, H. (1931). Canad. J. Res. 4, 372. 